\title{
EXPLORING ECONOMIC OPPORTUNITIES IN SOME SELECTED SPICES FARMING ENTERPRISE IN ONDO STATE, NIGERIA
}

\author{
Victoria Adeyemi Tanimonure ${ }^{\bowtie}$, Raphael Mayowa Yewande ${ }^{1}$, \\ Oreoluwa Grace Fayemi ${ }^{1}$
}

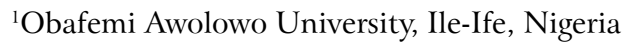

\begin{abstract}
This study explored the current economic issues and isolated constraints involved in the spice business in Ondo State, Nigeria. A quantitative research approach was used to elicit information from 60 randomly selected respondents through an individual interview schedule with the aid of a well-structured questionnaire. Data collected was explored using descriptive statistics, and budgetary and multiple regression analyses. The results showed that most (57\%) respondents were male, and $87 \%$ were married with a mean household size of 7 . Most $(77 \%)$ had at least a primary education, and all of them were members of an association with the majority $(78 \%)$ engaged in cooperative marketing of spices. Also, of the four selected spices, Aframomum melegueta, Piper guineese, Monodora myristica, Sylopia acthipea, only Aframomum melegueta was cultivated, others were gathered from the wild. The prominent constraints identified were the inability to propagate Piper guineese, Monodora myristica, and Sylopia acthipea; the lack of technology to harvest and dry Sylopia acthipea to meet the standard of the buyers; and the lack of access to high-value markets. The rate of return on investment was 0.98 , and the factors that determine the profitability of the spice business included the level of education, household size, labor and value addition. Research efforts should be focused on the propagation of $P$. guineese, M. myristica, S. acthipea, the technology for drying and harvesting of S. acthipea, and capacity building on value addition to increase business profitability.
\end{abstract}

Keywords: spices, profitability, enterprise, constraints

\section{INTRODUCTION}

Spices are dried part of plants that usually have strong and special smells/flavors. They can come from different parts of a plant, including: seeds, fruit, roots, bark, stems, rhizomes or flowers. There are about 50 spices of international importance and thousands of other less known local spices used for traditional cooking. Although many of these spices originated from Latin America, the Caribbean and Asia (especially India, China and Indonesia), many of them are now successfully grown across Africa.

The best-known use of spices is in food preparation and cooking. Traditionally and by research studies, spices have been known to function more than just been flavorants. It has found important use in ethno-medicine (Nasri et al., 2014; Awasthi and Pandey, 2016; Yashin et al., 2017), and this is the reason why consumers are turning more towards ethnic cuisine, spicy foods and the development of new uses for spices. Consequently, this has led to a drastic increase in the demand for spices among other herbs in the world market (UNIDO and FAO, 2005). In fact, the global demand forecast for herbs and spices, especially for their use as dietary supplements in complementary alternative medicine or orthodox medical practices, shows that it will continue on the upward trend. This provides a development opportunity for pharmaceutical raw materials.

World markets for spices and herbs, particularly in industrializing countries and in local markets, are

\footnotetext{
凶Victoria Adeyemi Tanimonure, Obafemi Awolowo University, P.M.B. 13 Ile-Ife, Osun, 220282 Nigeria, e-mail: vicofgodng@ yahoo.com, https://orcid.org/0000-0002-6490-3482
} 
expanding and can offer good returns to small-scale farmers. According to FAO data, there has been an increase in the quantity of spices produced globally. For instance, 2.10 million tons of spices were produced in 2012 globally, compared to 2.81 million tons in 2017. Asia is recorded to contribute about $94 \%$ to global spices production. India is the main producer in the continent, in 2017, 1.94 million tons of spices were produced in India (Factfish.com, 2020). In Nigeria, the potential in spices production is underutilized, and there is lack of information on how to cultivate and use them despite their economic importance (Adebayo et al., 2011). Therefore, there is good trade potential for small-scale farmers; they can benefit from spices as higher-value, low-volume cash crops to enhance their income and thus improve their livelihoods. A large proportion of spices traded in both local and export markets are produced by small-scale farmers. On a worldwide basis, trade in spices provides multi-billion U.S. dollar earnings for small-scale farmers (Ulhan et al., 2006; FAO, 2011).

Meanwhile, a literature review revealed that considerable work had been carried out to discover the importance of spices around the world. Most authors focused on the medicinal value of spices (De Milto and Fray, 2005; Nasri et al., 2014; Damanhouri and Ahmad, 2014; Fasoriyo, 2015; Yashin et al., 2017; Prasad et al., 2017). Also, there is a number of studies focused on spice consumption (Shinoj and Mathur, 2006; Akinpelu and Salman, 2015). Olife et al. (2013) and Adebayo et al., 2011 surveyed the production of spices in Nigeria but neglected the economic aspect. Akinpelu et al. (2011) also worked on the economic analysis of spices but their focus was on the marketing. Therefore, this research addresses four selected spices that are cultivated and/ or gathered by farmers in Ondo East Local Government area of Ondo State: Alligator pepper (Aframomum melegueta), African nutmeg (Monodora myristica), Eeru (Sylopia acthipea) and iyere (Piper guineese). The study seeks to explore the current status of spice production in the area, the profitability of the business, the constraints facing the spices enterprise and the factors that determine the profitability of the enterprise in the study area.

\section{METHODOLOGY}

\section{Descriptions of the study area}

The study area was Ondo State, located at latitudes between $5^{\circ} 45^{\prime} \mathrm{N}$ and $7^{\circ} 45^{\prime} \mathrm{N}$ and longitudes between $4^{\circ} 20^{\prime} \mathrm{E}$ and $6^{\circ} 03^{\prime} \mathrm{E}$. It is bounded by Edo and Delta States on the east, Ogun and Osun States on the west, Ekiti and Kogi States on the north, and the Bight of Benin and the Atlantic Ocean on the south. The state occupies a land area of about $15,000 \mathrm{~km}^{2}$ with a population of $3,441,924$ according to the 2006 census. The state has eighteen (18) Local Government Areas, with Akure as the capital city and the largest settlement. Agriculture is believed to be the mainstay of the people of Ondo State.

\section{Sampling procedure}

A multistage sampling technique was used in selecting the respondents for the study. At the first stage, Ondo East Local Government Area was purposively selected because of the presence of spice farmers in the area. Five villages (Bomodeoku, Oboto, Itaoba, Adaja and Akinseye), where spice farmers are organized into groups, were purposively selected at the second stage. At the third stage, twelve farmers were randomly selected from the list of spice farmers in each village to give a total of sixty respondents.

\section{Data collection and analytical techniques}

This study used a mixed-method research design involving both quantitative and qualitative research approaches to elicit information from the respondents selected. Primary data was used for this study. Data was collected using a well-structured questionnaire; a Focus Group Discussion was conducted to gain an in-depth understanding of various activities that are carried out in the spice business. Quantitative data collected was analyzed using descriptive statistics, and budgetary and multiple regression routines. In turn, discourse analysis was used for qualitative data.

\section{Budgetary technique}

The budgetary technique was used to analyze the costs and return rates of the selected spices business. The net revenue (NR) and profitability ratio were used to examine the profitability.

Revenue analysis is given by:

$$
\begin{gathered}
\mathrm{GM}=\mathrm{TR}-\mathrm{TVC} \\
\mathrm{NR}=\mathrm{GM}-\mathrm{TFC} \text { or } \mathrm{TR}-\mathrm{TC}
\end{gathered}
$$

where:

GM: Gross Margin, the difference between total revenue generated from the sales of the spices and total variable costs

TR: Total Revenue, the sum of the quantity of spices gathered or harvested multiplied by the average price per kilogram 
TVC: Total Variable Cost, the sum total of all the variable costs in the production of spices during the period

NR: Net Revenue, the difference between total revenue generated and total costs of inputs used in the production of spices

TC: Total Cost, the sum of both variable and fixed costs

TFC: Total Fixed Cost, the cost of variables that are fixed in the production of spices.

The performance and economic worth of the enterprise was determined using the following profitability ratios:

(1) Benefit cost ratio $(\mathrm{BCR})=\mathrm{TR} / \mathrm{TC}$

(2) Expense structure ratio $(\mathrm{ESR})=\mathrm{FC} / \mathrm{VC}$

(3) Ratio of return $(\mathrm{ROR})=\mathrm{NR} / \mathrm{TR}$

(4) Gross ratio $(\mathrm{GR})=\mathrm{TC} / \mathrm{T}$

\section{Multiple linear regression model}

The multiple linear regression analysis is a form of a predictive modeling technique which investigates the relationship between a dependent variable (target) and independent variables (predictors). This technique is used to find the causal effect relationship between the variables. Multiple linear regression was therefore used to establish a causal effect relationship between the net farm income accrued to spices farmers and selected socioeconomic variables. The coefficient of multiple determination $\left(\mathrm{R}^{2}\right)$ was obtained as a measure of goodness of fit. It is the percentage of total variation of the dependent variable (Y) explained by the variation in the independent variable $\left(\mathrm{X}_{1}-\mathrm{X}_{9}\right)$. The multiple regression equation and explanation of variables are expressed below as:

$$
\mathrm{Y}=\alpha+\beta_{1} \mathrm{X}_{1}+\beta_{2} \mathrm{X}_{2}+\beta_{3} \mathrm{X}_{3}+\beta_{\mathrm{n}} \mathrm{X}_{\mathrm{n}}+\varepsilon
$$

where:

$\mathrm{Y}=$ net farm income (dependent variable)

$\mathrm{X}_{1}=$ age of respondents (actual number)

$\mathrm{X}_{2}=$ gender $($ male $=1$, female $=0)$

$\mathrm{X}_{3}=$ marital status (married $=1$, single $=0$ )

$\mathrm{X}_{4}=$ years of formal education (years)

$\mathrm{X}_{5}=$ household size (actual number)

$\mathrm{X}_{6}=$ cost of labor $(\mathrm{NGN})$

$\mathrm{X}_{7}=$ farm distance from home $(\mathrm{km})$

$\mathrm{X}_{8}=$ value addition $(\mathrm{Yes}=1, \mathrm{No}=0)$

$\mathrm{X}_{9}=$ years of experience (years)

$\varepsilon=$ error term

\section{RESULTS AND DISCUSSION}

\section{Demographic characteristics of spice farmers}

The demographic characteristics of the respondents are presented in Table 1. The results showed that the average age of farmers involved in the spice business was

Table 1. Distribution of spice farmers by demographic characteristics $(n=60)$

\begin{tabular}{|c|c|c|c|}
\hline $\begin{array}{c}\text { Variables } \\
\text { description }\end{array}$ & Category & Frequency & $\begin{array}{c}\text { Percentage } \\
(\%)\end{array}$ \\
\hline 1 & 2 & 3 & 4 \\
\hline \multirow{3}{*}{$\begin{array}{l}\text { Age (age of the re- } \\
\text { spondents in actual } \\
\text { number) }\end{array}$} & $\leq 29$ & 3 & 5 \\
\hline & $30-59$ & 41 & 69 \\
\hline & $60-89$ & 47 & 26 \\
\hline Mean & & 54 & \\
\hline \multirow{3}{*}{$\begin{array}{l}\text { Marital status (in- } \\
\text { dicates whether the } \\
\text { respondent is mar- } \\
\text { ried or single) }\end{array}$} & Single & 7 & 12 \\
\hline & Married & 52 & 87 \\
\hline & No response & 1 & 1 \\
\hline \multirow{5}{*}{$\begin{array}{l}\text { Family size (actual } \\
\text { number of persons } \\
\text { in the respondent's } \\
\text { household) }\end{array}$} & $1-5$ & 29 & 48 \\
\hline & $6-10$ & 9 & 15 \\
\hline & $11-15$ & 11 & 18 \\
\hline & $16-20$ & 10 & 17 \\
\hline & No response & 1 & 2 \\
\hline Mean & & 7 & \\
\hline \multirow{2}{*}{$\begin{array}{l}\text { Gender (this dis- } \\
\text { tinguishes between } \\
\text { male and female } \\
\text { biological sex) }\end{array}$} & Male & 34 & 57 \\
\hline & Female & 26 & 43 \\
\hline \multirow{4}{*}{$\begin{array}{l}\text { Education (ac- } \\
\text { tual number of years } \\
\text { spent in formal } \\
\text { education) }\end{array}$} & Not educated & 20 & 33 \\
\hline & $1-6$ & 17 & 28 \\
\hline & $7-12$ & 16 & 27 \\
\hline & Above 12 & 7 & 12 \\
\hline Mean & & 6.65 & \\
\hline \multirow{4}{*}{$\begin{array}{l}\text { Experience (actual } \\
\text { number of years the } \\
\text { respondent has been } \\
\text { involved in the } \\
\text { spices business) }\end{array}$} & $1-20$ & 23 & 38.3 \\
\hline & $21-40$ & 27 & 45 \\
\hline & $41-50$ & 9 & 15 \\
\hline & $41-60$ & 10 & 16.7 \\
\hline Mean & & 26 & \\
\hline
\end{tabular}


Tanimonure, V. A., Yewande, R. M., Fayemi, O. G. (2020). Exploring economic opportunities in some selected spices farming enterprise in Ondo State, Nigeria. J. Agribus. Rural Dev., 1(55), 85-92. http://dx.doi.org/10.17306/J.JARD.2020.01228

Table 1 cont.

\begin{tabular}{llcc}
\hline \multicolumn{1}{c}{1} & \multicolumn{1}{c}{2} & 3 & 4 \\
\hline $\begin{array}{l}\text { Primary occupation } \\
\text { (occupation that } \\
\text { gives the highest } \\
\text { income) }\end{array}$ & $\begin{array}{l}\text { Agriculture-re- } \\
\text { lated activities }\end{array}$ & 48 & 80 \\
& $\begin{array}{l}\text { Formal private } \\
\text { employment }\end{array}$ & 7 & 12 \\
& $\begin{array}{l}\text { Public sector } \\
\text { employment } \\
\text { Artisan }\end{array}$ & 3 & $\mathbf{5}$ \\
\hline
\end{tabular}

Source: field survey, 2018.

ca. 54; the majority were between 30 to 59 years old, married, with an average family size of 7 . More (57\%) male farmers were involved in the business. While onethird of the sample respondents did not have a formal education, two-thirds attained different levels of formal education which affords them the opportunity to write and read and also access information that could enhance productivity. The average experience in the business was about 26 years; most (45\%) of the respondents had between 21 and 40 years of experience, and the primary occupation of the majority $(80 \%)$ was related to agriculture.

\section{Economic activities of spice farmers}

Table 2 presents various economic activities that spice farmers are engaged in. All (100\%) farmers were members of associations such as a cooperative; this had facilitated the marketing of the produce, as $78 \%$ sold their

Table 2. Distribution of spice farmers by economic activities

\begin{tabular}{|c|c|c|c|}
\hline $\begin{array}{l}\text { Variables } \\
\text { description }\end{array}$ & Category & Frequency & $\begin{array}{c}\text { Percentage } \\
(\%)\end{array}$ \\
\hline 1 & 2 & 3 & 4 \\
\hline \multirow{2}{*}{$\begin{array}{l}\text { Association in terms } \\
\text { of membership of } \\
\text { a cooperative }\end{array}$} & Yes & 60 & 100 \\
\hline & No & 0 & 0 \\
\hline \multirow[b]{2}{*}{$\begin{array}{l}\text { Marketing strategies } \\
\text { in terms of whether } \\
\text { the respondents pool } \\
\text { their produce to- } \\
\text { gether to market or } \\
\text { market individually }\end{array}$} & Cooperatives & 47 & 78 \\
\hline & Individuals & 13 & 22 \\
\hline
\end{tabular}

Table 2 cont.

\begin{tabular}{|c|c|c|c|}
\hline 1 & 2 & 3 & 4 \\
\hline \multirow{5}{*}{$\begin{array}{l}\text { Sales outlets in } \\
\text { terms of who buys } \\
\text { the spices from the } \\
\text { respondents }\end{array}$} & $\begin{array}{l}\text { Village } \\
\text { merchant }\end{array}$ & 10 & 17 \\
\hline & Broker & 3 & 5 \\
\hline & Cooperate & 41 & 68 \\
\hline & $\begin{array}{l}\text { Government } \\
\text { agency }\end{array}$ & 0 & 0 \\
\hline & Individuals & 6 & 10 \\
\hline \multirow{2}{*}{$\begin{array}{l}\text { Marketing strategy } \\
\text { satisfaction }\end{array}$} & Satisfied & 49 & 82 \\
\hline & Not satisfied & 11 & 18 \\
\hline \multirow{2}{*}{$\begin{array}{l}\text { Good pricing in } \\
\text { terms of whether or } \\
\text { not the respondents } \\
\text { have a good price } \\
\text { for their produce }\end{array}$} & Yes & 48 & 80 \\
\hline & No & 12 & 20 \\
\hline \multirow{2}{*}{$\begin{array}{l}\text { Profitability in terms } \\
\text { of how the respond- } \\
\text { ents perceive their } \\
\text { business profitability }\end{array}$} & Yes & 57 & 95 \\
\hline & No & 3 & 5 \\
\hline \multirow{2}{*}{$\begin{array}{l}\text { International market } \\
\text { in terms of whether } \\
\text { the respondents } \\
\text { have access to } \\
\text { international market } \\
\text { or not }\end{array}$} & Yes & 3 & 5 \\
\hline & No & 57 & 95 \\
\hline \multirow{2}{*}{$\begin{array}{l}\text { Business expansion } \\
\text { in terms of whether } \\
\text { the respondents } \\
\text { intend to expand } \\
\text { their business in the } \\
\text { future }\end{array}$} & Yes & 60 & 100 \\
\hline & No & 0 & 0 \\
\hline
\end{tabular}

Source: field survey, 2018.

produce through the cooperative they belong to. Also, membership of association afforded the majority of farmers $(68 \%)$ the opportunity to pool their produce and sell it to cooperative organizations. As a result, $82 \%$ testified to the fact that they were satisfied with the marketing strategy adopted by the cooperative. About $80 \%$ of the respondents received good pricing for their produce, and $95 \%$ attested to the fact that the business was profitable. Only $5 \%$ had connection with the international market; all the farmers desired business expansion in the nearest future. These findings suggest a promising future for the spice business in the study area. 
Tanimonure, V. A., Yewande, R. M., Fayemi, O. G. (2020). Exploring economic opportunities in some selected spices farming enterprise in Ondo State, Nigeria. J. Agribus. Rural Dev., 1(55), 85-92. http://dx.doi.org/10.17306/J.JARD.2020.01228

\section{Sources and quantity of spices} in the $2016 / 2017$ production year

As presented in Table 3, spices are either propagated or gathered from the wild. The result showed that only Aframomum melegueta is propagated while others were gathered. The quantity of Aframomum melegueta produced in 2016/2017 was $4,044 \mathrm{~kg}$. The quantity of $\mathrm{Mo}$ nodora myristica was the highest $(26,960 \mathrm{~kg})$ while $P i$ per guineese had the smallest quantity harvested during the $2016 / 2017$ production year.

Table 3. Sources and quantity of spices in the $2016 / 2017$ production year

\begin{tabular}{lcccc}
\hline \multicolumn{1}{c}{ Spices } & $\begin{array}{c}\text { Qty gathered } \\
(\mathrm{kg})\end{array}$ & $(\%)$ & $(\mathrm{kg})$ & $(\%)$ \\
\hline $\begin{array}{l}\text { Monodora } \\
\text { myristica }\end{array}$ & 26,960 & 88 & - & - \\
$\begin{array}{l}\text { Aframomum } \\
\text { melegueta }\end{array}$ & - & - & 4,044 & 100 \\
$\begin{array}{l}\text { Sylopia } \\
\text { acthipea }\end{array}$ & 2,160 & 7 & - & - \\
$\begin{array}{l}\text { Piper } \\
\text { guineese }\end{array}$ & 1,440 & 5 & - & - \\
\hline
\end{tabular}

Source: field survey, 2018.

\section{Constraints to spices production in the study area}

The constraints to the spice business identified in the study area are as follows: lack of access to credit; inability to propagate some spices; pests and diseases; inefficient local and international market; herdsmen, fire outbreak and deforestation; lack of adequate knowledge on the processing and storage to meet industrial standards (Table 4 ). About $21 \%$ of the farmers had no access to credit, and $25 \%$ were unable to propagate the desired type of spices as indicated in Table 4. Out of the four spices considered in the study, only one could be propagated by the farmers, the remaining three are gathered from the wild. Only $7 \%$ were faced with problems of pest and diseases; $26 \%$ had inefficient market channels and links with the international market; and 19\% had problems with processing and storage to meet industrial standards. These findings suggest that the farmers' inability to propagate some species of spices and inefficient
Table 4. Constraints faced by spice farmers

\begin{tabular}{|c|c|c|c|}
\hline Problems & Frequency & Percentage & Rank \\
\hline Lack of access to credit & 46 & 21 & $3^{\text {rd }}$ \\
\hline $\begin{array}{l}\text { Inability to propagate } \\
\text { some species of spices }\end{array}$ & 56 & 25 & $2^{\text {nd }}$ \\
\hline Pest and diseases & 15 & 7 & $5^{\text {th }}$ \\
\hline $\begin{array}{l}\text { Inefficient local and } \\
\text { international markets }\end{array}$ & 58 & 26 & $1^{\text {st }}$ \\
\hline $\begin{array}{l}\text { Herdsmen, fire outbreak } \\
\text { and deforestation }\end{array}$ & 5 & 2 & $6^{\text {th }}$ \\
\hline $\begin{array}{l}\text { Processing and stor- } \\
\text { age to meet industrial } \\
\text { standards }\end{array}$ & 43 & 19 & $4^{\text {th }}$ \\
\hline
\end{tabular}

Source: field survey, 2018.

market channels are the prominent problems they face in the study area.

\section{Profitability of the spice business}

Table 5 shows the estimated average costs of and returns on the spice business in the study area to be NGN 26,841.31 (USD 74.25) and NGN 437,024.58 (USD 1208.92) per annum, respectively. Among the cost components, labor inputs had the largest share (42\%) in total costs, followed by fertilizers/manure $(20 \%)$. Gross margin and net revenue were NGN 413,172.81 (USD 1142.94) and 410,183.50 NGN (USD 1,134.67), respectively. The benefit/cost ratio of 16.28 indicates that the spice business is highly profitable in the study area; this shows that about NGN (USD) 16.28 is to be realized on every NGN (USD) 1.00 investment in the spice business. This result is in line with Akinpelu et al. (2011) who found that the spice business is highly profitable.

\section{Determinants of profitability}

of the spice business in the study area

The multiple regression model was used to analyze the determinants of net income from the spice business in the study area. The adjusted $\mathrm{R}^{2}$ shows that all the explanatory variables included in the model jointly explained about $76 \%$ of the adjusted variability in the profit from spices. Also, the F-statistic was statistically significant at $1 \%$, whichindicatestheoverallsignificanceofthemodel.

Nine variables (age, gender, marital status, education, household size, labor, distance, value addition, and 
Tanimonure, V. A., Yewande, R. M., Fayemi, O. G. (2020). Exploring economic opportunities in some selected spices farming enterprise in Ondo State, Nigeria. J. Agribus. Rural Dev., 1(55), 85-92. http://dx.doi.org/10.17306/J.JARD.2020.01228

Table 5. Costs of and returns on the spice business in the 2016/2017 production year

\begin{tabular}{|c|c|c|c|}
\hline Items & Mean price/kg (NGN) & Mean amount (NGN) & $\%$ \\
\hline \multicolumn{4}{|l|}{ Revenue } \\
\hline $516.67 \mathrm{~kg}$ of Monodora myristica & $734.17(2.03)$ & $379,319.44(1,049.29)$ & \\
\hline $67.5 \mathrm{~kg}$ of Sylopia acthipea & $250(0.69)$ & $16,875.00(46.68)$ & \\
\hline $34.2 \mathrm{~kg}$ of Piper guineese & $600(1.66)$ & $20,571.43(56.91)$ & \\
\hline $67.53 \mathrm{~kg}$ of Aframomum melegueta & $300(0.83)$ & $20,260.00(56.04)$ & \\
\hline Total revenue & & $437,025.87(1,208.92)$ & \\
\hline \multicolumn{4}{|l|}{ Variable cost } \\
\hline Cost of seedling per unit & & $3,376.67(9.34)$ & 14 \\
\hline Cost of fertilizer/manure & & $4,685.80(12.96)$ & 20 \\
\hline Cost of chemicals & & $4,250.00(11.76)$ & 18 \\
\hline Cost of labor inputs & & $10,000.00(27.66)$ & 42 \\
\hline Cost of management & & $1,540.00(4.26)$ & 6 \\
\hline Total variable cost & & $23,852.47(65.98)$ & 100 \\
\hline $\operatorname{Gross}$ margin $(\mathrm{GM})=(\mathrm{TR}-\mathrm{TVC})$ & & $413,173.40(1,142.94)$ & \\
\hline \multicolumn{4}{|l|}{ Fixed cost } \\
\hline Depreciation on sprayer & & $1,468.72(4.06)$ & \\
\hline Depreciation on hoe & & $260.90(0.72)$ & \\
\hline Depreciation on cutlass & & $665.81(1.84)$ & \\
\hline Depreciation on file & & $85.65(0.24)$ & \\
\hline Depreciation on shovel & & $127.37(0.35)$ & \\
\hline Depreciation on fruit hooks & & $381.42(1.06)$ & \\
\hline Total fixed cost (TFC) & & $2,989.90(8.27)$ & \\
\hline Total cost $(\mathrm{TC})=(\mathrm{TFC}+\mathrm{TVC})$ & & $26,842.37(74.25)$ & \\
\hline Net income $(\mathrm{NI})=(\mathrm{GM}-\mathrm{TFC})$ & & $410,183.50(1134.67)$ & \\
\hline Benefit cost ratio $(\mathrm{BCR})=\mathrm{TR} / \mathrm{TC}$ & & 16.28 & \\
\hline Expense $/$ cost ratio $(\mathrm{ECR})=\mathrm{TFC} / \mathrm{TVC}$ & & 0.12 & \\
\hline Rate of return $(\mathrm{ROR})=\mathrm{NI} / \mathrm{TR}$ & & 0.94 & \\
\hline Gross ratio $=\mathrm{TC} / \mathrm{TR}$ & & 0.061 & \\
\hline Operating cost ratio $(\%)=\mathrm{TVC} / \mathrm{TR}$ & & 0.055 & \\
\hline
\end{tabular}

Figures in parenthesis are equivalent amounts in USD.

Source: field survey, 2018. 
Tanimonure, V. A., Yewande, R. M., Fayemi, O. G. (2020). Exploring economic opportunities in some selected spices farming enterprise in Ondo State, Nigeria. J. Agribus. Rural Dev., 1(55), 85-92. http://dx.doi.org/10.17306/J.JARD.2020.01228

Table 6. Determinants of profitability of the spice business in the study area

\begin{tabular}{lccc}
\hline Independent variables & Coefficients & Standard error & $p$-value \\
\hline Intercept & 4789.499 & 49178.02 & 0.922805 \\
Age & 164.8517 & 383.2194 & 0.668916 \\
Gender & 5168.657 & 8205.937 & 0.531649 \\
Marital status & -15821.2 & 12463.79 & 0.210186 \\
Education & 2693.985 & 4450.095 & $0.017667^{*}$ \\
Household size & 2117.243 & 1722.258 & $0.024698^{*}$ \\
Labor & -6132.83 & 6248.016 & $0.03104^{*}$ \\
Distance & -911.16 & 1770.85 & 0.609146 \\
Value addition & 25545.01 & 12741.35 & $0.050404^{*}$ \\
Experience & -169.394 & 329.0208 & 0.60893 \\
Constant & 4789.499 & 49178.02 & 0.922805 \\
F-value & $0.0104^{* *}$ & & \\
$\mathrm{R}^{2}$ & 0.7528 & & \\
Adjusted $\mathrm{R}^{2}$ & 0.689 & & \\
\hline
\end{tabular}

$* 5 \%$ significance level $* * 1 \%$ significance level.

Source: field survey, 2018.

experience) were included in the model. Four (education, household size, labor and value addition) out of nine included independent variables were found to be significant, as presented in Table 6.

The level of education of spice farmers in the study area was significant and positively related to net income $(p \leq 0.05)$; a one-year increase in the years of formal education will increase the level of net income by NGN 2,693.99 (USD 7.45). The model also revealed that household size is a major determinant of profit in the spice business. An additional household member increases spices profit by NGN 2,117.24 (USD 5.86). Value addition was also significant $(p \leq 0.05)$ and had a positive influence on net revenue from spices. An increase in the level of value added to the spices increased the farmers' net income by NGN 2,5545.01 (USD 70.66). This indicates that processed spice products, such as spices that have been removed from the pod, had more profit than spices sold without any level of processing. The model also showed labor as a significant but negative variable, which implies that an additional unit of labor will reduce the farmers' profit by NGN 6,132.83
(USD 16.96). These results corroborate the findings by Mariyono (2018) that while household size is a positive determinant of net income from vegetable business, the cost of labor has a negative impact.

\section{CONCLUSION AND RECOMMENDATIONS}

The study explores the economic opportunities in some selected spices business in Ondo State, Nigeria. The results indicated that only Aframomum melegueta are propagated by the farmers while Monodora myristica, Sylopia acthipea and Piper guineese are mostly gathered from the wild. The constraints faced by the farmers, in order of preference, are: inefficient local and international market; the farmers' inability to propagate some of the spices on their farmland; lack of access to credit facilities; lack of knowledge on how to process and store spices in order to meet the standards of specialized market outlets; problem of pests and diseases; and lastly, the problem of herdsmen, fire outbreak and deforestation. The results of the study further showed 
that the business is profitable: the rate of return on investment was 0.98 and the benefit/cost ratio showed that ca. NGN 17 is realized on every NGN 1 investment in the spice business. More so, the determinants of profitability of the spice business in the study area are education, household size, labor and value addition.

Based on these findings, the following is recommended:

- The study advocates research focus on the propagation of spices such as Monodora myristica, Sylopia acthipea and Piper guineese, that the farmers have difficulty in planting. Also, farmers need to be trained on how to plant them on their farmland.

- There should be training for the farmers on how to process and store their produce to meet specialized market demand.

- Also, the farmers should be trained on how to add value to some of these spices locally to boost their income.

\section{SOURCE OF FINANCING}

\section{Self-financed.}

\section{ACKNOWLEDGEMENT}

The authors acknowledged the cooperation of the sample respondents during the data collection.

\section{REFERENCES}

Adebayo, O. S., Adelaja, B. A., Akinpelu, C. A., Fariyike, T. A., Olajide-Taiwo, L. O. (2011). Survey of Spices Production in Nigeria. Acta Hortic. 911, 473-478 DOI: 10.17660/ ActaHortic.2011.911.55 https://doi.org/10.17660/ActaHortic.2011.911.55

Akinpelu, C. A., Adebayo, O. S., Adelaja, B. A., Adesegun, E. A., Aminu-Taiwo, R. B., Adeoye, I. B. (2011). An economic analysis of spices marketing in three selected states of Nigeria. Res. Crops, 12(3), 817-821.

Akinpelu, C. A., Salman, K. K. (2015). Demand for African Nutmeg and Scent Leaf Spice among Households in Imo State, Nigeria. J. Econ. Sust. Dev., 6(9). Retrieved from: www.iiste.org

Awasthi, K. K., Pandey, A. (2016). Utilization of Traditional Herbs, Spices, Seasoning and Condiments: A Case Study of the Preparation of "Buknu" in Selected Villages of Kanpur, Uttar Pradesh, India. Eur. J. Med. Plants, 14(1), 1-11.
Damanhouri, Z. A., Ahmad, A. (2014). A Review on Therapeutic Potential of Piper nigrum L. (Black Pepper): The King of Spices. Med Aromat Plants, 3, 3. http://dx.doi. org/10.4172/2167-0412.1000161.

De Milto, L., Fray, R. J. (2005). Nutmeg. In: J. L. Longe, Project gale encyclopedia of alternative medicine (vol. 13, pp. 1461-1463). Detroit: M I Thomson Gale.

Fact fish (2020). Spices, others, production quantity (tons) for all countries. Retrieved from: http://www.factfish.com/ statistic/spices $\% 2 \mathrm{C} \% 20$ others $\% 2 \mathrm{C} \% 2$ production $\% 20$ quantity

FAO (2011). Spices and herbs for home and market. Rome: Food and Agriculture Organization of the United Nations.

Fasoriyo, S. (2015). The value of spices; Uses, nutritional and Health benefits. LAP LAMBERT Academic Publishing, Germany.

Mariyono, J. (2018). Profitability and Determinants of Smallholder Commercial Vegetable Production. Int. J. Veg. Sci., 24(3). DOI: 10.1080/19315260.2017.1413698

Nasri, H., Sahinfard, N., Rafieian, M., Rafieian, S., Shirzad, M., Rafieian-Kopaei, M. (2014). Turmeric: A spice with multifunctional medicinal properties. J. Herb. Med. Pharm., 3(1), 5-8. Retrieved Jan 16 2019 from: https://www. researchgate.net/publication/285776797_Turmeric_A_ spice_with_multifunctional_medicinal_properties

Olife, I. C., Onwualu, A. P., Uchegbu, K. I., Jolaoso, M. A. (2013). Status Assessment of Spice Resources in Nigeria. J. Biol. Agric. Health., 3(9), 12-18.

Prasad, W., Khamrui, K., Mandal, S., Badola, R. (2017). Anti-oxidative, physico-chemical and sensory attributes of burfi affected by incorporation of different herbs and its comparison with synthetic anti-oxidant (BHA). J. Food Sci. Tech., 54(12), 3802-3809.

Shinoj, P., Mathur, V. C. (2006). Analysis of Demand for Major Spices in India. Agric. Econ. Res. Rev., 19(2), 367-376.

Ulhan, S., Demurel, R., Asan, A., Baycu, C., Kinaci, E. (2006). Colonial and Morphological Characteristics of Some Microfungal Species Isolated from Agricultural Soils in Eskißehir Province (Turkey). Turk. J. Bot., 30, 95-104.

UNIDO and FAO (2005). Herbs, Spices and Essential Oils: Post-harvest Operations in Developing Countries. Retrieved from: https://open.unido.org/api/documents/47887 81/download/HERB

Yashin, A., Yashin, Y., Xia, X, Nemzer, B. (2017). Antioxidant Activity of Spices and Their Impact On Human Health: A Review. International Analytical Center of Zelinsky Institute of Organic Chemistry of Russian. Academy of Science, 119991. 